\title{
CHALLENGES IN IMPLEMENTING ISLAMIC BANKING AND FINANCE IN NIGERIA: A LEGAL INSIGHT
}

\author{
Muhammad Bashir Alkali ${ }^{1}$ \\ Ahmad Hidayat Buang ${ }^{2}$
}

\begin{abstract}
God's Laws, as contained in the Scriptures, form the nucleus of society. They are therefore a veritable social mechanism for enhancing Christian-Muslim partnership. This is especially true in economic relationships, such as Banking and Finance in the pluralist society of Nigeria; as Islamic Banking and Finance (IBF) is now accepted in non-Muslim nations worldwide. The licensing by the Governor of the Central Bank of Nigeria in 2011 of the then Jaiz Bank International PLC, the first fully fledged Islamic Bank in Nigeria, triggered a soaring Muslim-Christian relationship. The methodology of concurring provisions of the Quran and the Bible on the subject of finance; and inferences to the acceptance of IBF by non-Muslim nations can be used to harmonize application of IBF in society. The objective is to create a conducive legal, economic and social atmosphere for the
\end{abstract}

1 PhD Candidate, Department of Shariah and Law, Academy of Islamic Studies, University of Malaya, 50603 Kuala Lumpur \& Dean, Faculty of Law, Yobe State University, Nigeria, bashir@siswa.um.edu.my

2 Professor, Department of Shariah and Law, Academy of Islamic Studies, University of Malaya, 50603 Kuala Lumpur \& Member of Shariah Supervisory Council, Bank Islam Malaysia Berhad, ahidayat@um.edu.my 
smooth, acceptable and uncontroversial operation of IBF through demonstration of the scriptural and international unity on IBF. It is also to enhance peace, unity and prosperity in Nigeria as obtained in other pluralist and secular environments worldwide. The study proved that all scriptural laws have the common goal of ensuring societal prosperity, good health and peaceful coexistence. The IBF symbolizes and seeks to provide those benefits in Nigeria, as are obtained in other jurisdictions sharing the legacy of legal and judicial pluralism founded during the period of British colonial rule.

Keywords: Christian-Muslim peaceful and prosperous co-existence, 1999 Nigerian Constitution, legal pluralism, Islamic banking and finance

\section{INTRODUCTION}

As we learn to hate, we should also learn to love one another irrespective of color and religion ${ }^{3}$; IBF stands a force to be reckoned with in pursuit of this unifying ambition. Nigeria due to its diversity and legal pluralism has a complex legal system which consist of English, customary and Islamic law as the sources of laws. Due to early contact of the southern part of Nigeria with the Western colonialists, the southern part of the country has been greatly influenced by English law and Christianity, in addition to the pre-colonially existent customary laws. The north, particularly Borno and Yobe states, on the other hand, had contact with Islam as far back as the $9^{\text {th }}$ Century and hence the predominance of Shariah in the Region. ${ }^{4}$ The Central Bank of Nigeria (CBN) announced on Monday 20 June 2011 that it had issued Jaiz International Bank PLC an Approval in-Principle, as the first fully fledged Islamic bank in the country. The announcement was made at an Islamic banking conference in Dakar, Senegal. The Central Bank had earlier, in 13 January 2011, approved for the Jaiz Bank to carry on business as a Profit and Loss Sharing Bank and issued a Framework on Non-Interest Financial Institutions (NIFI). It was approved by the national legislature and has a $60 \%$ non-Muslim patronage. The government approved the establishment of IBF after the CBN Governor,

3 CNN, Nelson Mandela 1918-2013, http://edition.cnn.com/2013/12/05/africa/ gallery/mandela-quotes/index.html ?sr=fb120513mandelaquotes530p, accessed 5 December 2013 (on the eve of his demise on this day)

4 James Burns \& Robert Collins, A History of Sub-Saharan Africa (Cambridge: Cambridge University Press, 2007), 89. 
Sanusi, convinced the parliament and the Finance Minister that non-Muslims are also free to interact with the bank as exemplified by USA and Britain. ${ }^{5}$

Islamic banking (IB), otherwise referred to as non interest banking, has gained popularity across the globe with both Muslims and non-Muslims. In the words of Sanusi, ${ }^{6}$ IB is an alternative form of financial intermediation that is based on the Islamic value system, it is not the only form of profit and loss sharing bank based on non-interest principles, but it is the most developed form that has international acceptance and recognition. Though IB is based on a religious law it is not a religious product or service that is exclusively meant for people of a particular creed. It is universally accessible to and enjoyed by people of diverse religious persuasions or ethical beliefs across the globe. ${ }^{7}$

In Europe, (France in particular), where there is a considerable ArabMuslim population because of -their colonial history, the question is no longer how to establish an Islamic state or Islamize positive laws; but how to interpret and practice a 'law' that is not backed by a state. Shariah revolves around two poles in France. On the one hand, we have the salafi Shariah discourse, framing Shariah as morality 'oriented towards a code'. On the other, we have the discourse on Shariah whereby Shariah has been 'ethicized', that is, where it is no longer framed as a law, assuming instead the form of religious ethics. ${ }^{8}$

5 Turaki Hassan, 'Reps okay Islamic banking, $60 \%$ of Jaiz shareholders are Igbo,' Transparency Nigeria.com., published 22 July 2011 http://www.transparencyng. com/index.php/news-categories/117-politics/4920-reps-okay-islamic-banking60-of-jaiz-shareholders-are-igbo-sanusi Accessed June 26, 2014 See also http:// www.transparencyng.com/index.php/news-categories/117-politics/4920-repsokay-islamic-banking-60-of-jaiz-shareholders-are-igbo-sanusi, 26 June 2014.

6 Sanusi is currently the Emir (King) of Kano State and the immediate fast Governor of the Central Bank of Nigeria and he had taken appreciable measures towards ensuring that IBF smoothly operates in Nigeria. He was suspended from his CBN Governorship for exposing \$46 billion (later reduced to \$20 billion) the President diverted from crude oil sales within a year. Fortunately for him the Governor of Kano State, Engineer Rabiu Kwankwaso, appointed him the Emir of Kano to succeed his late brother Emir Ado Bayero. http://saharareporters.com/news-page/ breaking-news-former-central-bank-governor-lamido-sanusi-emerges-new-emirkano accessed 27 June 2014. See also http://www.gongnews.net/sanusi-makesfresh-20-billion-missing-oil-money-claim/, accessed 27 June 2014.

7 Sanusi Sanusi, 'Islamic Finance in Nigeria: Issues and Challenges,' (A lecture delivered at Markfield Institute of Higher Education, UK, 17 June 2011).

8 Manni Crone, 'Shari 'a and Secularism in France,' Islam and Christian-Muslim Relations 22/4 (2011): 156. 
The purpose of writing this paper is to suggest a legal atmosphere that will enhance the smooth operation of the IBF system in Nigeria, for the benefit of all the people irrespective of religious creeds. This could be achieved through identifying the legally-based complaints against IBF and proffering legal solutions. Sources of the solutions can be provisional statutory amendments, mass mobilization and Scriptural legal provisions, as they provide a coherent platform for the removal of religious bias on this subject. This is sine quo non to the desired success of IBF in Nigeria.

\section{THE CONCEPT OF NIGERIAN LEGAL PLURALISM}

The Nigerian legal system is made up of the following constituents:

(a) Nigerian Legislation

Nigerian legislation is basically divided into Acts enacted by the Senate and House of Representatives. ${ }^{9}$ Laws made by the state Houses of Assembly and Bylaws made by the local Governments. ${ }^{10}$ The National Assembly has powers to legislate on matters in the exclusive and concurrent legislative list, while the state Houses of Assembly legislate on matters in the concurrent legislative list. ${ }^{11}$

(b) English Law

This refers to laws received from the colonialists, consisting English Common Law, Doctrines of Equity and Statutes of General Application in force in England on or before the $1^{\text {st }}$ of January $1900 .{ }^{12}$ The root of the received English law is undoubtedly Christianity; This position is supported by Lord Summer in Bowman vs. Secular Society ${ }^{13}$ :

"Ours is and always has been a Christian state. The English family is built on Christian ideas, and if the national religion is not Christianity there is none. English law may well be called a Christian law, but we apply many of its rules and most of its principles with equal justice and equally good government, in heathen communities and its sections even in courts of conscience..."

\footnotetext{
9 Section 47, Nigerian Constitution 1999.

10 Section 4, Nigerian Constitution 1999.

11 Section 4, Nigerian Constitution 1999.

12 Akintunde Obilade, The Nigerian Legal System (Ibadan: Spectrum Law Publishing, 1979), 4.

$13 \quad 1917$ Appeal Cases 406.
} 


\section{(c) Customary Law}

This consists of cultures and traditions of the community that has over the years become a mirror of accepted usage by the native community. ${ }^{14}$ Some attempted to classify Islamic law as customary law but the apex court in Nigeria (the Supreme Court) declared in the case of Alkamawa vs. Bello ${ }^{15}$ that Islamic law is not the same as customary law, for it does not belong to any particular time, it is more certain and universal than even the English common law.

(d) Islamic Law

Islamic Law is the law (revealed by Allah) that is designed to govern the relationship between a Muslim and his Creator ( 'ibādat) and relationship of a Muslim with other creatures (mu' $\bar{a}$ malät). ${ }^{16}$ The Quran is the compilation of Allah revealed to the Prophet (PBUH) through Angel Jibril (AS). It serves as a code of guidance to Muslims and is the first primary source of the Shariah. The second primary source of the Shariah is the Sunnah which consists of the sayings, actions and tacit approvals of the Prophet (PBUH). Both are the primary sources of the Shariah. ${ }^{17}$ While ijmā', consensus opinion of Muslim Jurists, and qiyās, analogical deduction of a Muslim jurist based on the Quran and Sunnah, are the secondary sources. Istihsān, istișlāh, mașālih al-mursalah, 'urf or 'ádat make up the subsidiary sources of Islamic Law. ${ }^{18}$

\section{EVOLUTION OF ISLAMIC BANKING IN NIGERIA}

Various forms of money lending were practiced, in 1903, in the pre-colonial Sokoto caliphate of Nigeria, which presently consists of more than half of present day Northern Nigeria. ${ }^{19}$ A case was reported of a successful Hausa business man in the 1930-40s, Alhaji Al Hasan, who used to find outlets for surplus capital. He advanced money to young men of sound business acumen, requiring them to pay him half of their business profit, or less at times, if no profit was made. When he eventually banked with conventional banks, he was reported to have refused interest for religious reasons though he accepted good

\footnotetext{
14 Akintunde Obilade, The Nigerian Legal System, 4.

151998 NWLR (pt 561) 173.

16 Mohammed Sule, 'Islamic Concept of the International Law (The Siyar),' Ahmadu Bello University Law Journal vol. 27-28 (2008): 48.

17 Abdurrahman Doi, Sharia: The Islamic Law (Kano: Al-Yassar Publishers, 2007), 21-58.

18 Abdurrahman Doi, Sharia: The Islamic Law, 64-85.

19 AbdulQadir Abikan, 'Constitutionality of Islamic Banking in Nigeria,' in Contemporary Jurisprudence in Islamic Jurisprudence (Benin: Rawel Fortune Resources, 2009), 96.
} 
customer gifts at the end of the year. ${ }^{20}$ Abubakar Orisankoko ${ }^{21}$ made a brief statement on the historical background of IBF in Nigeria when he said:

"Usually, most indigenous authors, academia and scholars have continuously reviewed the historical background of Islamic/NonInterest Banking in Nigeria and majority seem to center their focus on the defunct Habib Nigeria Bank Ltd as the first Islamic variant-banking model to have opened a window for Non-Interest banking while Jaiz International PLC is regarded the nip-board of the full-fledged Islamic Bank in Nigeria. Al-Baraka Micro Finance is taken for the pioneer Islamic Micro-finance while Lotus Capital Investment Limited is regarded as the primal Islamic Finance and investment institution in Nigeria."

No mention was made of IB until the coming into force of the Banks and other Financial Institutions Decree No. 25 of 1991 following pressure by Muslims to have banks that comply with the principles of Shariah. Habib Bank attempted to open a window of non-interest banking, but that commendable effort fell short of achieving continuity due to the absence of a legal framework. ${ }^{22}$ The Central Bank of Nigeria, on 11 September 2011, issued a license to Jaiz Bank PLC, to operate Sharia-compliant banking in Nigeria. It is currently operating with branches in Abuja, Kano and Kaduna, all in Northern Nigeria. It is hoped that with the unprecedented patronage and support the new Jaiz Bank is enjoying, it is here to stay despite the Abuja High Court decision in 2012 that it is illegal although it did not withdraw its license. ${ }^{23}$ The facts and decision of the case are discussed below under the grounds for opposition to IBF in Nigeria.

20 AbdulQadir Abikan, 'Constitutionality of Islamic Banking in Nigeria,' 94 -121.

21 Abubakar Orisankoko, 'Socio-Economic and Legal Challenges of Shari'aCompliant Banking Operation, its Developmental Impacts and the Struggles of the Believers: Epistemological Lessons from Nigeria,' Journal of Islamic Economics, Banking and Finance 8/2 (Apr-Jun 2012): 49.

22 Alhaji Ibrahim, 'Islamic Finance in Nigeria: Challenges and Options,' (Graduation Ceremony of the 6th Daurah on Hadith of the Centre for Memorization of Hadith West Africa in Bauchi, Nigeria, 26 July 2011), http://www.ndic.org.ng/islamicfinance-in-nigeria-challenges-and-options-by-alhaji-umaru-ibrahim-managingdirector-ceo-ndic-at-the-graduation-ceremony-of-the-6th-daurah-on-hadith-ofthe-centre-for-memorisation-of-hadith-west-africa-in-bauchi-on-26th-july-2011. html., accessed 27 June 2014.

23 Justice Gabriel of the Abuja High Court case of Sunday Ogboji vs. CBN and 2 others (unreported), africainvestor Magazine of 18/6/12, www.africainvestor.com/ article.asp?id=10461, accessed 27 June 2014. 


\section{THE GROUNDS FOR THE OPPOSITION TO IBF IN NIGERIA}

The inability of many Nigerians to separate religion or politics from the economy has led to heated debate on the desirability of the bank. The ongoing controversy motivated this study to examine non-interest banking regardless of religious coloration and recommend the way it can serve as an agent of economic transformation; in a nation with 17 percent unemployment and an absolute poverty rate of about 70 percent. ${ }^{24}$ Opposition to the establishment of the Bank was climaxed by one Sunday Ogboji's application to an Abuja High Court seeking the nullification of its license on the grounds, inter alia, that it is unconstitutional as it is tantamount to declaration of a state religion and discriminates against non-Muslims. On 15 June 2012, Justice Gabriel Kolawale of Abuja Federal High Court declared, by obita dictum, the Bank license as ultravires null and void, although fortunately did not withdraw the license:

1.1 There are no provisions in the CBN Act and the Banks and other financial Institutions Act (BOFIA) that empowers the CBN Governor Sanusi Lamido Sanusi to issue license for non-interest financial institution to operate under the principles of Islamic jurisprudence without the approval of the head of state through the minister of finance.

1.2 That unlike the other specialized banks, the Jaiz International Bank PLC can only be established in the country with the intervention of the National Assembly by amending the BOFIA Act.

1.3 If not that the plaintiff has no locus Standi to maintain this action, I would have nullified the illegal license issued to the Jaiz International Bank PLC by the CBN to operate non-interest banking under the principles of Islamic jurisprudence.

1.4 That this case is hereby struck out for lack of locus Standi, but the AGF should take steps to remedy the situation, and further ensure that the CBN carries out its duties within the provisions of the law establishing it. ${ }^{25}$

\footnotetext{
24 Alao Oladimeji \& Esther Mon, 'Islamic Banking: The Controversy Over NonInterest Banking System in Nigeria,' Arabian Journal of Business and Management Review (Nigerian Chapter) 1/1 (2012): 65 \& 74.

25 Justice Gabriel in the Abuja High Court case of Sunday Ogboji vs. CBN and 2 others (unreported).
} 
The court was silent about the applicant's plea to declare the licensing of the bank as tantamount to declaring Islam as a state religion and economic discrimination based on religion contrary to Sections 10 and 16 (1) (d) of the constitution. This paper seeks to defend the CBN position with the aim of encouraging excellent Christian-Muslim relationships by demonstrating the unity, parity and concurrence between the Quran and the Bible on the characteristics of IBF.

It is the view of Anglican Bishop of Enugu, Rt. Emmanuel Chukwuma that the $\mathrm{CBN}$ is not constitutionally empowered to grant a license to the establishment of any Islamic Bank. As reported by Nkwopara, Rt. Rev. Geoffrey Chukwunenye and Ven. H., U Nnaoma respectively signed a 14point communiqué alluding that the action of the CBN Governor is contrary to Section 10 of the Constitution and an infringement of human rights. They further justified their position of correctness citing the effect of Section 39 (1), BOFIA 1991, which they claimed must have led to the removal of Shariah that was repeated in the purported Draft Framework for the regulation of NIBs in Nigeria.

Section 10 of the Nigerian Constitution 1999 provides:

"The Government of the Federation or of a State shall not adopt any religion as a State Religion."

Section 16 1(d) provides:

"Without prejudice to the right of any person to participate in areas of the economy within the major sector of the economy, protect the right of every citizen to engage in any economic activities outside the major sectors of the economy."

The Central Bank of Nigeria has no legislative power or the power to interpret non-interest banking to mean Islamic banking only:

"CBN should sponsor a bill in the National Assembly if it must add anything to the extant laws. It cannot use a framework to change the law. It is not due process."

[The Apostles in the Market Place (AiMP)]

The Apostles in the Market Place (AiMP), a group of professionals, joined the bandwagon to challenge the legality of this move. The approach of these professionals is more violent and less intellectual; it is tantamount to war declaration. Capturing this scenario better, Elbaff recounts that: 
"From the spirit and substance of the various presentations all but the presentation made by Brett Johnson were vehemently opposed to the whole concept of Islamic Banking. " 26

The oppositions to IBF are more or less based on religious sentiments rather than principled constructive criticism.

\section{ARGUMENTS FOR ISLAMIC BANKING IN NIGERIA}

The following are evidence to buttress the true good image of IB and its acceptance by some logically thinking non-Muslims whose identities are contained in the footnotes. They sound objective, unbiased and seem to comprehend the positive impact the IBF system will have on any given society irrespective of the faith.

5.1 Indeed, any man-made law is meant to protect the legitimate Right of all the members of the community. In this regard, the right of those who want to (continue) undertake their financial dealings based on interest is by no means more sacred than that of those who want to avoid interest 'Riba' in all its forms. ${ }^{27}$

5.2 From the political perspective, to any rational-thinking person, the issue is much simpler because the Act governing the conduct and operations of the CBN, the Banking and Other Financial Institutions Act (BOFIA. 1991, section 23[1] and section 66) explicitly provides for the licensing of non-interest banks (NIBs). ${ }^{28}$

5.3 Islamic Bank has all rights to bear and answer any chosen name given the entrenched judgment made by the Court of Appeal, Nigeria in the case of Offoboche v. Offoboche (2007). ${ }^{29}$

26 Elbaff Ja, Provocations of Islamic Banking Antagonists, http://dailytrust.dailytrust. com/index.php?option $=$ com_content $\&$ view $=$ article $\& i d=21716$ :provocationsof-islamic-bankingantagonists\&catid=7:opinion\&Itemid=12), accessed 19 June 2014; Abubakar Orisankoko, 'Socio-Economic and Legal Challenges of Shari'aCompliant Banking Operation,' 56.

27 Elbaff Ja, Provocations of Islamic Banking Antagonists.

28 Elbaff Ja, Provocations of Islamic Banking Antagonists.

29 Abubakar Orisankoko, 'Socio-Economic and Legal Challenges of Shari'aCompliant Banking Operation, Its Developmental Impacts and the Struggles of the Believers: Epistemological Lessons from Nigeria,' Journal of Islamic Economics, Banking and Finance 8/2 (Apr-Jun 2012): 56. 
5.4 The CBN is not doing anything illegal but it has wielded its derivative powers as a government agency operating under the Nigerian laws. Moghalu submitted further that the latest guideline did not narrow NIB to Sharia principles anymore. The Nigerian laws provide adequately for non-interest banking and $C B N$ cannot under the law decline to register and license NonInterest Financial Institutions (NIFIs). ${ }^{30}$

5.5 Islamic banking is just a name as it is a non-faith, non-biased and notrestricted to Muslims. About 60 per cent of the shareholders of Jaiz are Igbos from the South-East. Discrimination is strictly prohibited. It is open to Christians and everybody. Islamic banking is operating in 75 countries of the world including Britain, USA, South Africa, Kenya and Malaysia. ${ }^{31}$

5.6 Non-Interest Banking is a veritable means of providing access to capital to the un-banked and those who would ordinarily not qualify for debt financing. ${ }^{32}$

5.7 The establishment of an Islamic bank does not necessarily tally with the Islamisation of the Nigerian economy as critics may suppose, though such Islamisation may be desirable for the fulfillment of a basic tenets of Islam; the running by Muslims of their economic affairs in line with their religion. ${ }^{33}$

5.8 A Bishop in the Dioceses of Chris Temple Ministry International, Bishop Goodluck Akpore, said opponents of Islamic Banking in Nigeria are ignorant of the products the bank offers as it is not against Christians in the country. ${ }^{34}$

30 Kingsly Moghal, The Evil of Usury, http://www.biblebelievers.org.au/usury. htm\#The\%20Evil\%20of\%20 Usury, accessed 23 June 2014.

31 Sanusi Sanusi, 'Islamic Finance in Nigeria: Issues and Challenges.'

32 Eghes Eyieyie, 'The Central Bank of Nigeria, Islamic Banking, the Law and Appropriate Regulation of Non-Interest Financial Regulation in Nigeria,' Elombah Perspective of World Affairs, http://elombah.com/index.php/articles /70 v15, 27 June 2011, accessed 23 June 2014.

33 Mohammad Ahmad \& Izzatullah, 'Islamic Banking Laws: Feasibility of Implementation in Nigeria,' International Comparative Law Report (ICLR) 14 (1994): 116.

34 Bishop, 'Bishop Urges Christians to Embrace Islamic Banking,' Economic Confidential Magazine, http://economicconfidential.net/new/financial/monetary/ 1027-bishop-urges-christians-to-embrace-islamic-banking, accessed 17 September 2013. 


\section{EVIDENCE OF THE ACCEPTANCE OF ISLAMIC BANKING AND FINANCE IN NON-MUSLIM NATIONS}

The West has no permanent enemies or friends but interest in and hence their acceptance of IBF for its economic benefits for their nations; below are examples of such non-Islamic nations:

Switzerland: "Last week the Swiss authorities granted a banking licence to Faisal Private Bank. The Geneva based bank will be the first in Switzerland to operate according to Islamic law (Sharia) principles. The latter prohibit usury, the collection and payment of interest, trading in financial risk, women opening bank accounts without their husband's approval, etc. Sharia products also cannot be invested in companies involved in gambling, alcohol, tobacco, pornography and the production of pork." 35

Beside the economic gain associated with IBF, the prohibitions of alcohol, tobacco and pornography could as well be a factor for the acceptance of the system as the negative effects of the said items are enormously bedeviling the West.

France: "French Finance Minister Christine Lagarde has announced France's intention to make Paris "the capital of Islamic finance" and announced several Islamic banks would open branches in the French capital in 2009. " 36

This move was later hijacked by Britain, which went to the extent of hosting the Annual Global IBF Conference this year, 2014.

The Vatican: In yet another act of conciliation on the part of Western religions towards Islam, the Vatican newspaper Osservatore Romano has voiced its approval of Islamic finance. The Vatican paper wrote that banks should look at the rules of Islamic finance to restore confidence amongst their clients at a time of global economic crisis.

"The ethical principles on which Islamic finance is based may bring banks closer to their clients and to the true spirit which should mark every financial service," the Osservatore Romano

35 Paul Belien, 'First Sharia Bank in Switzerland,' The Brussels Journal, http://www. brusselsjournal.com /node/1479, 10 July 2006, accessed 17 September 2013.

36 Tiberge, 'Vatican Paper Supports Islamic Finance: France Wants Its Share of Sharia Banking,' The Brussels Journal, 2009, http://www.brusselsjournal.com/ node/3819, accessed 17 September 2013. 
said. "Western banks could use tools such as the Islamic bonds, known as sukuk, as collateral". Sukuk may be used to fund the "car industry or the next Olympic Games in London," the article says. ${ }^{37}$

England: "HSBC, Lloyds TSB, and Citigroup have opened Islamic banking units and branches throughout England. In 2005 the first stand-alone British Islamic bank, Islamic Bank of Britain, opened its doors. Middle Eastern Islamic banks have also set up shop in the UK." 38

The Netherlands: A quote from Wouter Bos, the Dutch Finance Minister (and leader of the Dutch Labour Party), 16 July 2007:

"We want to encourage Islamic banking; in the first place because Islamic banking meets a demand from the Muslims living in the Netherlands. In the second place because we see an opportunity here for the Dutch financial sector; a third reason is that banning Islamic banking from the perspective of fighting terrorism will have a counter-productive effect. Denial of an actual need can lead to money-flows running via alternative channels out of the sight of the government. ",39

Those three rationales for the Netherlands' acceptance of the system are logical and will serve as a campaign for the system in the rest of the world, where it is not yet accepted.

\section{PEACE AS A PRODUCT OF ECONOMIC BUOYANCY}

The Qur'anic injunctions allow trade, sale and creation of debt which is in implicit terms recognizing legitimate profit. Forty out of the 6,666 verses of the Quran provide for this subject. Apart from one important verse on performing contracts which enjoins believers to keep faithful to contracts, ${ }^{40}$ there are three

\footnotetext{
37 Tiberge, 'Vatican Paper Supports Islamic Finance: France Wants Its Share of Sharia Banking.'

38 Helena Christofi, 'Islamic Banking in Britain,' The Brussels Journal, 2009, http:// www.brusselsjournal.com/node/1898, accessed 17 September 2013.

39 Wouter Bos, 'The Netherlands Want to Become Centre of Sharia Banking,' The Brussels Journal, http://www. brusselsjournal.com/node/2256, accessed 17 September 2013.

40 Surah al-Mā'idah, verse 1.
} 
verses with a common theme of keeping promise ${ }^{41}$ and there are a few verses which reveal a relatively advanced stage of commercial contracts, such as sale and hire, charges or personal guarantee as (security) and fiduciary contracts such as deposits. ${ }^{42}$ The Quran approves legitimate trade as follows:

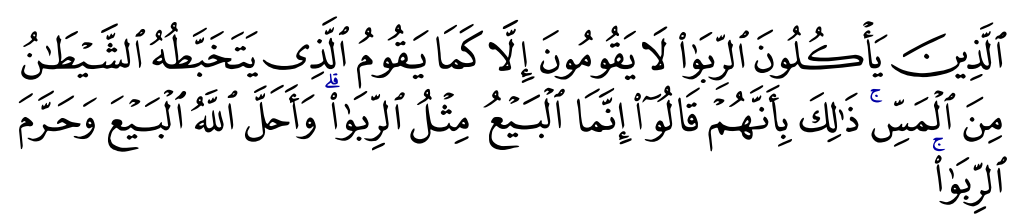

"Those who devour usury will not stand except as stands one whom the Evil One by his touch hath driven to madness. That is because they say: "Trade is like usury," but Allah hath permitted trade and forbidden usury."

(Surah al-Baqarah, 2: 275)

This is in fact encouraged by the obligation to pay religious alms or zakāh which indirectly necessitates the accumulation of wealth. Additionally and more importantly, the Hadith of the Prophet Muhammad, may peace be upon him, buttresses the view that poverty leads to crime through his sayings:

$$
\begin{aligned}
& \text { كاد الفقر ان يكون كفرا } \\
& \text { "Poverty can lead to kufr (disbelieve and crime)" } 43
\end{aligned}
$$

IBF can be used as a machinery to enhance the economic buoyancy of nations and individuals; it could enormously check crime rates and partake in the national struggle to appease the religious insurgents in Nigeria who are mostly poor and unemployed.

\footnotetext{
41 Surah al-Isrā’ verse 3.

42 Zulkifli Hasan and Hisham Sabri, Uqud in Financial Services for Entrepreneurship, http://search.tb.ask.com/search/GGmain.jhtml?st=sb\&ptb=E4967466-D69B45C2-8340554BE19DCA6C\&n=77fda78f\&ind $=2013$ 112207\&p2 $={ }^{\wedge} \mathrm{HJ}^{\wedge} \mathrm{xdm} 073$ ${ }^{\wedge} \mathrm{YYA}^{\wedge}{ }^{\mathrm{my}} \& \mathrm{si}=$ pconvFF$\&$ searchfor $=$ verses + of + the + Quran + on + trade + and + sales, accessed 27 June 2014.

43 Al-Bukhārī, Șaḥịh al-Bukhārī, Hadith number 8, 840 vol. 7 (Beirūt: Dār al'Arabiyyah, 1980).
} 


\section{PROHIBITION OF RIB $\bar{A}$ AND CHEATING BY THE QURAN}

Both scriptures have forbidden usury as in the following verses:

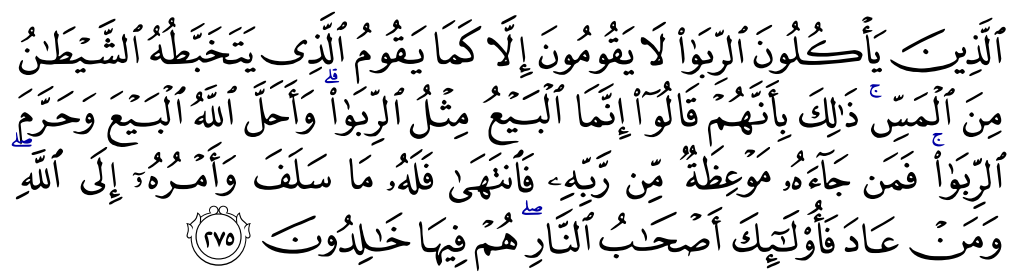

"Those who devour usury will not stand except as stands one whom the Evil One by his touch hath driven to madness. That is because they say: "Trade is like usury," but Allah hath permitted trade and forbidden usury. Those who after receiving direction from their Lord, desist, shall be pardoned for the past; their case is for Allah (to judge); but those who repeat (the offence) are companions of the Fire: they will abide therein (forever)"

(Surah al-Baqarah, 2: 275)

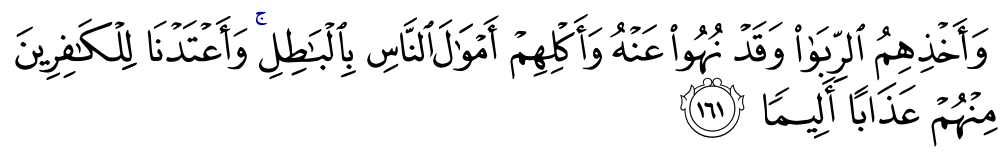

"That they took usury, though they were forbidden; and that they devoured men's substance wrongfully; We have prepared for those among them who reject Faith a grievous punishment"

(Surah al-Nisā', 4:161)

The most forbidden type of rib $\bar{a}$ is where the repayment is doubled and multiplied. The Quran provides:

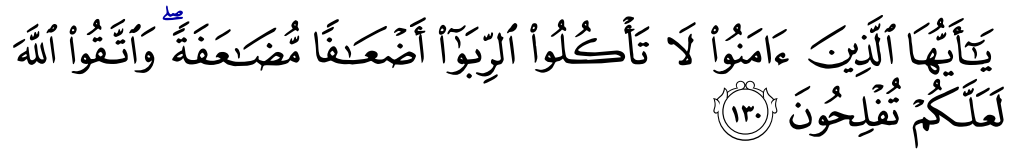

"O ye who believe, Devour not usury, doubled and multiplied; but fear Allah; that ye may (really) prosper."

(Surah Āli-'Imrān, 3:130)

Dealing in usury is tantamount to wickedness, cruelty and cheating and therefore forbidden and cursed of blessing: 


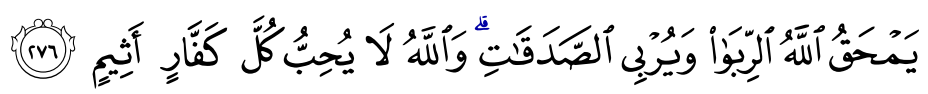

"Allah will deprive usury of all blessing, but will give increase for deeds of charity: for He loveth not creatures ungrateful and wicked."

(Surah al-Baqarah, 2: 276)

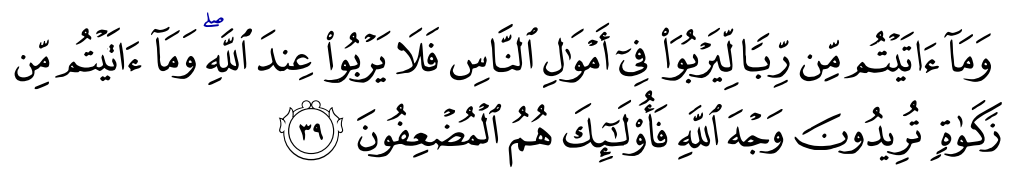

"That which ye lay out for increase through the property of (other) people, will have no increase with Allah: but that which ye give for charity, seeking the Countenance of Allah (will increase): it is these who will get a recompense multiplied."

(Surah al-Rūm, 30: 39)

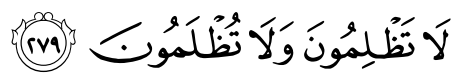

"Deal not unjustly and ye shall not be dealt with unjustly!"

(Surah al-Baqarah, 2: 279)

The latest verse prohibiting cheating, and allowing being cheated, poses the question as to whether or not interest in fixed deposit accounts is legal where both the bank and the depositor have mutual benefit. However, the fact that the depositor gets his fixed profit even when the bank is at a loss casts doubt on the Shariah compliance of the deal. The Christians in Nigeria enormously partake in the system because of the effect of those verses on the system.

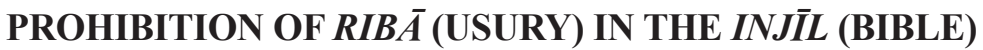

The Bible, just as in the Quran, equally illegalizes usury as it enshrines:

"If you lend money to My people, to the poor among you, you are not to act as a creditor to him; you shall not charge him interest." ${ }^{44}$

44 New American Standard Bible Exodus 22:25. 
Exactly as the Quran prohibits rib $\bar{a}$ and enjoins charity, the Bible has a parallel provision:

"One who is gracious to a poor man lends to the LORD, and He will repay him for his good deed." 45

The charging of usury on loans is "one of the oldest professions of man."46 The original banking system was the Temple Priests system, followed by the Goldsmiths and the contemporary commercial bankers. The earliest operation of the fractional reserve system was in the Temple of Shamash under Hammurabi, the sixth king of Babylon. ${ }^{47}$ The ecclesiastical doctrine of interest was the greatest hindrance to modern banking. It was mainly based upon 1) Aristotle's criticism of interest as an unnatural breeding of money by money, 2) Christ's (supposed) denunciation of interest ${ }^{48}$ and the response of the Fathers of the Church against commercialism and usury in Rome. ${ }^{49}$ The moral disapproval of this ancient practice has been summarized:

"It comes as news to most people to learn that practically all important ethical teachers - Moses, Aristotle, Jesus, Mohammed, and Saint Thomas Aquinas, for instance - have denounced lending at interest as usury and as morally wrong. " 50

Usury has been illegalized since biblical times. ${ }^{51}$ It was originally regarded usurious to make any charge for the use of money. Originally the word interest

\footnotetext{
45 New American Standard Bible Proverbs 19:17.

46 Forrest Smith, 'The Regulation of Interest: Practice and Procedure,' The Evil of Usury, in Maisel, article from New Dawn Magazine, http://www.biblebelievers. org.au/usury.htm\#The\%20Evil\%20of\%20Usury, accessed 23 June 2014.

47 Peter Cook, Federal Reserve Fractional Reserve and Interest-Free Government Credit Explained (Monetary Science Pub., 1991), 4 - Federal Reserve banks.

48 Bible, Luke 6:34.

49 Will Durant, 'The Age of Faith 630, 1950,' in Maisel, The Evil of Usury, Article From New Dawn Magazine, http://www.biblebelievers.org.au/usury.htm\#The\%20 Evil\%20of\%20Usury, accessed 23 June 2014.

50 Lawrence Dennis, 'The Squirrel Cage of Debt,' Saturday Review of Literature 661, 24 June 1933.

51 George Braden, The Constitution of The State of Texas: An Annotated and Comparative Analysis (Texas: Texas Library Resources, 1977), 729, http://www. sll.texas.gov/library-resources/collections/bradens-annotated-texas-constitution/, accessed 28 December 2014.
} 
had the same essential meaning as usury. ${ }^{52}$ The word "usury" used to mean any interest. It came to mean interest that exceeds the rate established by law. ${ }^{53}$

Interest comes from the Latin verb "intereo" meaning to be lost; ${ }^{54}$ the early Israelites called usury " a bite." It is like the slow poison of a serpent:

"Usury does not all at once destroy a man or nation with, as it were, a bloody gulp. Rather, it slowly, sometimes nearly imperceptibly, subverts the victim's constitution until he cannot prevent the fatal consequences even though he knows what is coming." 55

The practice of lending to an enemy was "as a means of destroying him." "56

According to the Old Testament:

"Classes the usurer with the shedder of blood, the defiler of his neighbor's wife, the oppressor of the poor, the spoiler by violence, the violator of the pledge, the idolater, and pronounces the woe upon them, that they who commit these iniquities shall surely die." 57

The usurer was categorized with extortionists, Sabbath-breakers, those who vex the fatherless and widows, dishonor parents and accept bribes. ${ }^{58} \mathrm{He}$ was also branded with the liar, the unrighteous, the backbiter, the slanderer and perjurer, and denied the right to inherit the New Jerusalem. ${ }^{59}$ The usurer is additionally categorized with the meanest and lowest of men and the vilest of criminals. ${ }^{60}$ Before the Babylonian captivity, Ezekiel denounced the practice

52 Forrest Smith, 'The Regulation of Interest: Practice and Procedure,' in Maisel, The Evil of Usury, article from New Dawn Magazine, http://www.biblebelievers.org. au/usury.htm\#The\%20Evil\%20of\%20Usury, accessed 23 June 2014.

53 Ken Warner, 'Give Us A King,' in Maisel, The Evil of Usury, article from New Dawn Magazine, http://www.biblebelievers.org.au/usury.htm\#The\%20Evil\%20 of $\% 20$ Usury, accessed 23 June 2014.

54 Maisel, The Evil of Usury, article from New Dawn Magazine, http://www. biblebelievers.org.au/usury.htm\#The\%20Evil\%20of\%20Usury Accessed 23 June 2014.

55 Mooney, 'Usury', http://www.biblebelievers.org.au/usury.htm\#The\%20Evil\%20 of\%20Usury, accessed 23 June 2014.

56 Jno Kimmons, Usury: What Is It, and Does The Law of God Forbid It?, http:// www.biblebelievers.org.au/usury.htm\#The\%20Evil\%20of\%20Usury, accessed 23 June 2014.

57 Old Testament 2.

58 Ezekiel 22.

59 Psalm 15.

60 Ezekiel 18. 
of usury, as a great evil and mentioned the practice of oppressing strangers as part of the great wickedness. ${ }^{61}$ Interest repayments on loans, even to resident strangers, were forbidden in the year of Jubilee ${ }^{62}$ whereas in regular years it was permissible to charge interest to strangers. ${ }^{63}$ Nehemiah, after the captivity, boldly denounced usury, ${ }^{64}$ instituted a reform and had retribution made for all usurious holdings:

"He that putteth not out his money to usury."

Solomon gave us the proverb:

Jesus taught:

"The borrower is servant to the lender." 65

"Love ye your enemies, and do good and lend, hoping for nothing again." 66

Usury was the basis for Jesus's calling the money changers thieves:

"The commerce of the world is conducted on principles as much at variance with the teachings of the master, as are the practices of a sneak thief or burglar. So the Master taught, as with whip of cords, he indignantly drove its representatives, from the sacred precincts of the Temple, denouncing them as thieves. Every wellinformed mind knows that the money changers in the Temple, on that startling occasion, were at the very center of the Jewish Banking system, and of the pitiless and grinding commerce of Palestine." 67

In Jesus' parable on the subject of usury:

"Only the hard, austere man, one whose conscience will not interfere with his reaping where he has not sown, and taking up where he has not laid down, would extract usury, for he makes the lord of the parable tell the servant of it: You say I am a hard and

\footnotetext{
61 Ezekiel 9.

62 Leviticus 25:35-37.

63 Deuteronomy 23:19-20.

64 Nehemiah 5:9-11.

65 Nehemiah 15.

66 Luke 6:34-3.

67 Luke 19.
} 
austere man, then why did you not act accordingly, and earn me my usury as my nature demanded?" 68

The Apostle Peter publicly told his vision:

"And in another lake, full or pitch and blood and more bubbling up, there stood men and women on their knees: and these were usurers and those who had taken interest."

Antinicene Fathers, Vol. IX, p. 146. The Apostle Paul, in telling his vision, said:

"And I saw another multitude of men and women, and worms consumed them. But I lamented and sighing asked the angel and said, 'Who are these?' And he said to me: These are those who exacted interest $O N$ interest, and trusted in their riches and did not hope in God that He was their helper." 69

\section{EMULATING SARDAUNA BY THE PRESENT NIGERIAN LEADERSHIP: A POTENT MUSLIM-CHRISTIAN UNIFYING MECHANISM}

It is pertinent to state that political will is sine quo non in uniting the citizenry who are divided across religious inclination although it will sometimes be at a cost to the political leader. Sardauna, Sir Ahmadu Bello, was the Premier of Northern Nigeria who fought for the unity of the Muslims and Christians in Nigeria but was assassinated by the Christians in 1963. Maitama Sule, the first Nigerian representative to the United Nations, was quoted as having said that he remembered the Sardauna helping to form the Northern Association of Christians of Nigeria, which later went national and became the Christian Association of Nigeria. ${ }^{70}$

The Quran and the Bible, as religious laws, have both recognized profit and loss sharing transactions and have prohibited usury, uncertainty and ambiguity relating to business subject matter, terms or conditions; gambling; speculation; unjust enrichment; exploitation/unfair trade practices; dealings in pork; alcohol; drug abuse; arms and ammunition, pornography; and all transactions, products, goods and services which are not compliant with the rules and principles of Islamic and Christian commercial jurisprudence. The abhorrence

\footnotetext{
68 Matthew 25:26-27; Luke 19:22-23.

69 Antinicene Fathers, The Lie, Usury, and Spiritual Discernment, vol. IX, 160, http://www.biblebelievers.org.au /usury2.htm, accessed 8 March 2014.

70 Donu Kogbara, 'Failure of Northern Elders,' Vanguards News Paper, 24 September 2013, http:/www.vanguardngr.com/2013/08/failure-of-northern-elders/\#sthash. g0bbek6w.dpuf, accessed 24 September 2013.
} 
of IBF is therefore not based on the true Christian jurisprudence but narrow sentimentalism which negates societal peace and prosperity. Accordingly, there is a need for mass mobilization and political will to achieve the goal of uniting Muslims and Christians in Nigeria towards peaceful co-existence and prosperity through IBF.

\section{CONCLUSION AND RECOMMENDATIONS}

From the foregoing, it could be concluded that the laws in both Christianity and Islam, pertaining to banking and commerce, have a common goal; the economic enhancement through non-exploitative transactions such as banking without riba (interest) and shunning harmful products. These are factors which should ordinarily unite Christians and Muslims. The opposition to IBF in Nigeria is rooted on religious sentiments, rather than logical human reasoning, as there is nowhere in any of the mundane and spiritual laws where interest free banking is illegalized. Islamic bankers say stricter Shariah laws governing the operations of Islamic banking help improve profitability. Both ROA (return on assets) and ROE (return on equity) in Islamic banking normally remain higher than that of the overall banking industry. According to the latest SBP bulletin, annualized ROA and ROE at 1.6 percent and 17.8 percent for Islamic banking were better than the two ratios for overall banking 1.5 percent and 15.8 percent respectively. ${ }^{71}$ This is good for society irrespective of religious creed, as our common enemy is unemployment, poverty and crime, which could be tackled through streamlining the Nigerian laws relating to I.B, for instance by appointing a Christian into the CBN and Jaiz Bank Sharia Advisory Councils, to make it as acceptable to non-Muslims in Nigeria as it is obtained in nonMuslim nations worldwide. This is the concern of this study which concurs with ideas of Alao D. and Aloa E.M.: ${ }^{72}$

"Reason and objectivity should guide individual position on the issue (IBF in Nigeria) as poverty is not a respecter of any of the religious groupings."

71 Dawn.com, Growth in Islamic Banking, http://dawn.com/news/736467/growthin-islamic-banking, accessed 22 August 2013.

72 Alao Oladimeji \& Aloa Monisola 'Islamic Banking: The Controversy over Non-Interest,' Arabian Journal of Business and Management Review (Nigerian Chapter) 1/1 (2012): 67. 


\section{REFERENCES}

AbdulQadir Abikan, 'Constitutionality of Islamic Banking in Nigeria,' in Contemporary Jurisprudence in Islamic Jurisprudence (Benin: Rawel Fortune Resources, 2009).

AbdulQadir Abikan, 'The Legal Framework for Islamic Banking in Nigeria,' Usman Danfodio University Journal of International Comparative Law $2(2010)$.

Abdurrahman Doi, Sharia: The Islamic Law (Kano: al-Yassar Publishers, 2007).

Abu Muhammad Ibn Abu Zaid, Risala, Lessons 93-104. 3h2, Basic Maliki FIQH, Qayrawani kayrawani, Amira Zrein Matraji HB 279PP (Lebanon: Dar al-Fikr, 1994).

Abubakar Orisankoko, 'Socio-Economic and Legal Challenges of Shari'aCompliant Banking Operation, Its Developmental Impacts and the Struggles of the Believers: Epistemological Lessons from Nigeria,' Journal of Islamic Economics, Banking and Finance 8/2 (Apr-Jun 2012).

Africanoutlookonline, Nigeria and Islam Finance, available at http://www. africanoutlookonline.com/index.php?option=com_content\&view=art icle\&id=3817:nigeriaislam-finance-islamic-banking-finally-starts-innigeria, accessed 12 March 2014.

Akintunde Obilade, The Nigerian Legal System (Ibadan: Spectrum Law Publishing, 1979).

Alao Oladimeji \& Alao Monisola, 'Islamic Banking: The Controversy Over Non-Interest,' Arabian Journal of Business and Management Review (Nigerian Chapter) 1/1 (2012).

Al-Hafīz al-Asqalānī \& Muhammad al-Sanan̄̄, Bulūgh al-Marām (Riyāḍ: Dār Assalam Publication, 1996).

Antinicene Fathers, The Lie, Usury, and Spiritual Discernment Vol. IX, http:// www.biblebelievers.org.au/usury2.htm accessed 8 March 2014.

Black's Law Dictionary (Centennial Edition 1891-1991) at Amazon.com.

Al-Bukhārī, Șaḥịh al-Bukhārī (Beirūt: Dār al-'Arabiyyah, 1980).

Central Bank of Nigeria, Draft Framework for the Regulation and Supervision of Non-Interest Banking in Nigeria, circular Number BSD/ Dir/NIB/01/008 (published on 4 March, 2009).

Chiroma Muhammad, 'Legal Feasibility and Economic Viability of Establishing Islamic Banking: An Analysis under the Nigerian Legal Framework,' University of Ibadan Law Journal 1/1 (2001). 
Dawn.com, Growth in Islamic Banking, http://dawn.com/news/736467/ growth-in-islamic-banking, accessed 22 August 2013.

Donu Kogbara, 'Failure of Northern Elders,' Vanguards News Paper, http:// www.vanguardngr.com/2013/08/failure-of-northern-elders/\#sthash. g0bbek6w.dpuf, 24 September 2013.

Economic Confidential Magazine, Bishop Urges Christians to Embrace Islamic Banking, http://econo micconfidential.net/new/financial/ monetary/1027-bishop-urges-christians-to-embrace-islamic-banking, accessed 17 September 2013.

Eghes Eyieyie, 'The Central Bank of Nigeria, Islamic Banking, the Law and Appropriate Regulation of Non-Interest Financial Regulation in Nigeria,' Elombah Perspective of World Affairs, http://elombah.com/index.php/ articles/70 v15, 27 June 2011, accessed 23 June 2014.

Elombah Perspective of World Affairs, Regulation of Non-Interest Financial Regulation in Nigeria, http://elombah.com/index.php/articles/70letters/7115-the-central-bank-of-igeriaislamic-banking-the-law-andappropriate-regulation-of-non-interest-financial-institutions-in nigeriav15-7115, 27 June 2011.

Encyclopedia of Islam, http://en.wikipedia.org/wiki/Jesus_in_Islam, accessed 16 September 2013.

First Bank of Nigeria, www.firstbanknigeria.com/about-us/our-history/, accessed 12 March 2014.

Forrest Smith, 'The Regulation of Interest: Practice and Procedure,' in Maisel, The Evil of Usury, article from New Dawn Magazine, http://www. biblebelievers.org.au/usury.htm\#The\%20evil\%20of\%20usury, accessed 23 June 2014.

Gafai Abdullah, 'Comparative Analysis of the Rights of Women in Sharia and Common Law in Contemporary Nigeria,' Journal of Islamic Science and Contemporary Development 2 (2010).

George Braden, The Constitution of The State of Texas: An Annotated and Comparative Analysis, 1977.

Helena Christofi, 'Islamic Banking in Britain,' The Brussels Journal, http:// www.brussels journal.com /node/1898, 2 December 2009, accessed 17 September 2013.

http://www.muhammadanism.org/Islam/Islam_Way_Life.htm., accessed 12 March 2014. 
Islamic Finance and ISRI, Any Cross Over? Working paper May 2009 at part 3 p. 12 available at www.novethic.com and http://www.responsible-investor. com/images/uploads/resources/research /11248094270Working_paper_ on_islamic_finance_and_SRI.pdf, 12 March 2014.

Jamal Elbaff, Provocations of Islamic Banking Antagonists, http://dailytrust. dailytrust.com/index.php?option=com_content\&view=article\&id=2171 6:provocations-of-islamic-bankingantagonists\&catid=7:opinion\&Itemi $\mathrm{d}=12$, 4 July 2011.

James Burns \& Robert Collins, A History of Sub-Saharan Africa (Cambridge: Cambridge University Press, 2007).

Jno Kimmons, Usury: What is It, and Does the Law of God Forbid It, Maisel, The Evil of Usury, article from New Dawn Magazine, http:// www.biblebelievers.org.au/usury.htm\#The\%20Evil\%20of\%20Usury, accessed 23 June 2014.

Jorgen Nielsen \& Lisbet Christoffersen, Shari 'a as Discourse: Legal Traditions and the Encounter with Europe (Farnham, UK: Ashgate, 2010).

Ken Warner, 'Give Us a King,' Maisel, The Evil of Usury, article from New Dawn Magazine, http://www.biblebelievers.org.au/usury.htm\#The\%20 Evil\%20of\%20Usury, accessed 23 June 2014.

Kpr37, The Nigerian Jihad in Historical Perspective (The Sokoto Caliphate and Boko Haram), www.newsvine.com., accessed 12 March 2014.

Lawrence Dennis, 'The Squirrel Cage of Debt,' Saturday Review of Literature 661, 24 June 1933.

Manni Crone, 'Shari 'a and Secularism in France,' Islam and Christian-Muslim Relations 22/4 (2011).

Mohammad Ahmad \& Izzatullah, 'Islamic Banking Laws: Feasibility of Implementation in Nigeria,' International Comparative Law Report (ICLR) 14 (1994).

Mohammed Sule, 'Islamic Concept of the International Law (The Siyar),' Ahmadu Bello University Law Journal (ABULJ) 27-28 (2008).

Muhammad Abdul-Fattah, 500 Questions and Answers on Islamic Jurisprudence, ed. Reima Shakeir (Dār al-Manara, 2006).

New American Standard Bible Exodus.

Nigeria Weekly Law Report (NWLR) 1998.

Paul Belien, First Sharia Bank in Switzerland, The Brussels Journal 1008-2006, http:/www.brusselsjournal.com/node/1479, accessed 17 September 2013. 
Peter Cook, Federal Reserve Fractional Reserve and Interest-Free Government Credit Explained (Monetary Science Pub., 1991), 4 - Federal Reserve banks.

Robert Collins, 'Kanem: Decline and Merge with Borno,' (c. 1400) in Encyclopedia of African History, ed. Kevin Shillington (New York: Fitzroy Dearborn, 2005).

Sandra Keating from Ridwan al-Sayyid \& Adel Daher, 'The Challenge of Pluralism: Paradigms from Muslim Contexts,' Islam and ChristianMuslim Relations 22/4 (2011).

Sanusi Sanusi, 'Islamic Finance in Nigeria: Issues and Challenges,' (Lecture delivered at Markfield Institute of Higher Education, UK., 17 June 2011).

The Apostles in the Market Place (AiMP), a group of professionals formed to kick against IBF in Nigeria.

Tiberge, 'Vatican Paper Supports Islamic Finance: France wants Its Share of Sharia Banking,' The Brussels Journal (2009), http://www. brusselsjournal.com/node/3819, accessed 17 September 2013.

Turaki Hassan, 'Reps okay Islamic banking, 60\% of Jaiz shareholders are Igbo,' Transparency Nigeria.com, published on 22 July 2011.

UNESCO/Nigeria Instructional/Teaching Materials, Development of Commercial Banking in Nigeria, http://unesconigeriatve.org/ teaching\%20materials/acc/accountancy/semester1/BFN\%20111\%20 Elements\%20of\%20banking\%201/week6.html., accessed 12 March 2014.

Wikipedia, Jaiz Bank Plc., Nigeria, http://en.wikipedia.org/wiki/Jaiz_Bank, 18 November 2012.

Wouter Bos, 'The Netherlands Want to Become Centre of Sharia Banking,' The Brussels Journal, 17 July 2007, http://www.brusselsjournal.com/ node/2256, accessed 17 September 2013.

Yusuf Ali, The Glorious Qur'an, Text, Translation and Commentary, the Amazon, 2012.

\section{Statutes}

Banks and Other Financial Institutions Act (BOFIA) 1999.

Central Bank Act 2003 (Nigeria).

Nigeria Deposit Insurance Corporation (NDIC) Act 2006.

Nigerian Constitution 1999. 


\section{Cases}

Alkamawa vs. Bello 1998 NWLR (pt 561) 173.

Bashirat Saliu and 2 Others vs. the Provost Kwara State College of Education Ilorin and 2 Others (Unreported-Kwara State High Court case/suit no.kws/28m/2006 ruling delivered $8^{\text {th }}$ May, 2006).

Bowman vs. Secular Society 1917 A.C. 406.

Sunday Ogboji vs. CBN and 2 others (unreported Abuja Federal High Court Case), of 18/6/ accessed 12 March 2014. 
Jurnal Syariah, Jil. 23, Bil. 1 (2015) 141-166 